\title{
Traditional management of Cactaceae by local populations in the semi-arid region of Brazil
}

Kamila Marques Pedrosa ${ }^{1 *}$; Sérgio de Faria Lopes ${ }^{1}$; Thamires Kelly Nunes Carvalho2; Camilla Marques de Lucena ${ }^{3}$; Ailza Maria de Lima-Nascimento ${ }^{4}$ and Reinaldo Farias Paiva de Lucena ${ }^{2 *}$

\begin{abstract}
Cactaceae species are important resources in the semi-arid region of Brazil and have been used and managed in a specific way by farmers to optimize and ensure the availability of cacti to rural communities. Thus, this study aimed to investigate management techniques used by residents of four rural communities in the municipality of Cabaceiras, Paraíba, Northeast Brazil. Only residents who claimed to perform some type of cacti management participated in this study, totaling 17 informants. Pilosocereus gounellei (F.A.C. Weber) Byles \& Rowley subsp. gounellei, Cereus jamacaru DC. subsp. jamacaru, Pilosocereus pachycladus F. Ritter, Tacinga palmadora (Britton \& Rose) N.P. Taylor \& Stuppy, and Melocactus zehntneri (Britton \& Rose) Luetzelb. Ex situ and in situ management techniques were recorded. The first one performed by transplantation of propagules and the second one by tolerance. The species propagation is carried out using shoots and vegetative parts. Of the species identified, only Cereus jamacaru subsp. jamacaru has more than one form of management. In addition to management, informants use rudimentary techniques such as burning the vegetative parts for fodder purposes.
\end{abstract}

Keywords: Caatinga; Traditional knowledge; Ethnobotany.

\footnotetext{
1* State University of Paraíba, Department of Biology, Campina Grande, Paraiba, Brazil.

$2^{*}$ Federal University of Paraíba. Exact and Natural Sciences Center. Department of Systematics and Ecology. Laboratory of Ethnobiology and Environmental Sciences. Campus I. João Pessoa, Paraíba, Brazil.

3* UNIESP University Center, Cabedelo, Paraíba, Brazil.

4 Federal University of Pernambuco, Biological Science Center, Recife, Pernambuco, Brazil.

* Corresponding author. $\triangle \mathrm{E}$-mail address: KMP (kamila_biopb@hotmail.com), SFL (defarialopes@gmail.com), TKNC (carvalhotkn@gmail.com), AMLN (ailzamlima@gmail.com), RFPL (rlucena@dse.ufpb.br).
}

\section{SIGNIFICANCE STATEMENT}

Throughout the dry season, species of cactus are one of the most important food sources used by the farmers to feed their animals. To understand the management of these species, it is important to support conservation practices, which approach local interests in an unpredictable future. In our study, we show how human groups managed species in domestic and natural environments. Investigations of traditional management can contribute to the discussion about plant domestication and conservation. Understanding how these people use and manage cactus species is also important because, due to climate change, these plants have been in demand for constant use, which may put them at imminent risk of local extinction. 


\section{INTRODUCTION}

The northeast region of Brazil is mostly characterized by semi-arid climate and $P$ occurrence of xerophytic vegetation (Sbrissa et al. 2012), but despite these limiting environmental conditions, it is home to more than 28 million people, most of them living in rural areas (Silva et al. 2017). The use and management of plant resources, available for various purposes (fodder, medicinal, rural constructions, and food), are common and necessary for residents of rural communities (Lucena et al. 2015). Recent studies have frequently recorded the use of Cactaceae species in this region of Brazil (Lucena et al. 2012, 2013, 2015; Lucena et al. 2017).

Ethnobotanical and domestication studies on these species have investigated the capacity of human activity to influence their availability, considering their genetic and ecological aspects as a function of the use of different management practices (Apodoca 2001; Casas et al. 2001; Fuentes 2005; Fernández-Alonso 2006; Blancas et al. 2010; Lucena et al. 2012, 2013, 2015).

The understanding of the term management consists of intentional activities (or not), which are practiced with the objective of maintaining or modifying a system and/or its elements (Gepts 2004). Such activities may involve the use, conservation or restoration of a resource or environment (Casas and Parra 2016a). Certain Cactaceae species are managed by human populations, specifically by selecting specimens with characteristics that meet the demand for consumption (Casas et al. 2001), and this occurs both in natural environments (in situ) and outside them (ex situ) (Casas et al. 2001, 2006).

The in situ management has been characterized in [1] tolerance - when the resource is maintained in its environment at the time of land preparation and even after its preparation; [2] protection - it is based on practices such as removal of competitors, pest control and protection against environmental effects; [3] promotion practices that make possible the species population development, consisting of propagation of vegetative parts or seeds, and/or by pruning; [4] cultivation - occurs in both wild and ex situ managed populations. The cultivation is carried out using seeds, vegetative parts or transplantation of young plants to environments directly managed by the people; this practice is classified as ex situ management (Casas et al. 1997a; González-Insuasti and Caballero 2007).

Thus, there is a need to study the forms of management involving useful Cactaceae species, performed by rural communities in the semi-arid region of Brazil, considering that each technique may interfere in different ways and degrees of complexity with the environment and managed resource (Lucena 2018). Furthermore, understanding how human experience contributes to the development of strategies for using plants may be useful in developing plans for exploiting and conserving biodiversity. This assertion is reinforced by the cultural and utilitarian importance of Cactaceae species, which are threatened with extinction due to indiscriminate exploitation, land use and occupation in Brazil and other regions of the world (Martorell et al. 2012).

Thus, this study aimed to investigate the interest in traditional management techniques of Cactaceae species, between residents of four rural communities in the semi-arid region of Paraiba, northeastern Brazil. 


\section{MATERIAL AND METHODS}

\section{Study area}

This research involved residents of the rural communities of Tapera, Caiçara, Rio Direito, and Caruatá de Dentro, located in the municipality of Cabaceiras $\left(07^{\circ} 29^{\prime} 20^{\prime \prime} \mathrm{S}\right.$ and $36^{\circ} 17^{\prime \prime} 14^{\prime \prime} \mathrm{O}$ ), state of Paraíba, northeastern Brazil (Figure 1). This municipality is $167 \mathrm{~km}$ from the state capital (João Pessoa), about 300 meters above sea level, accounting for a population of 5,035 inhabitants, of which 2,217 live in the urban area and 2,818 in the rural area (IBGE 2010).

The study area has a Bsh climate, hot semi-arid (Álvares et al. 2013), and annual rainfall between 350 and $600 \mathrm{~mm}$, highly variable in space and time (Moro et al. 2015). The annual mean temperature is $26^{\circ} \mathrm{C}$, with minimum values in July and August and maximum values in November and December (Nascimento and Alves 2008). These climatic conditions determine a seasonally dry tropical forest (SDTF) vegetation, with physiognomic variety and endemic biodiversity (Silva et al. 2017). The region is characterized by the occurrence of plant species physiologically and morphologically adapted to the weather conditions, such as trees and shrubs, with small leaves, and twisted thorny stems, and succulent species (Queiroz et al. 2017).

\section{Data collection}

\section{Legal and ethical aspects}

This study was carried out after being approval (CEP/HULW No. 297/11) by the Health Committee's guidelines and regulations (Resolution 196/96), through the Ethics and Research Committee (CEP) of the Federal University of Paraíba. All participants signed the Free and Informed Consent Form (ICF), allowing the publication of the obtained ethnobotanical information.

\section{Ethnobotanical data}

The study communities were selected due to the fact there were family ties between one of the researchers and the communities' residents, which contributed to greater access and reliability to obtain information from the respondents. It was not possible to interview all residents because some of them were sick and others were absent when researchers visited their homes. The nonparticipant observation technique was used to identify residents who performed the traditional management of cacti (Albuquerque et al. 2014). The data were collected between November 2016 and November 2017, using semi-structured questionnaires with specific questions about the management of Cactaceae species (Lucena et al. 2015). The questionnaire addressed questions on the use, knowledge, and management of Cactaceae (e.g., What cacti do you use? Do you grow any cactus? How is the planting performed? Where do you collect the plants? What is the care for the development of the plants?).

In situ and ex situ management categories (Casas 1997a, 2007, 2014; Blancas et al. 2010) were considered to analyze how local populations perform traditional management techniques. Thus, in situ management may be performed through [1] collection (obtainment of useful plant parts), [2] tolerance (non-removal of wild plants from areas used for agropastoral activity), [3] induction (propagation through vegetative parts of specimens of a given population), and [4] protection (desirable plants are protected through management 

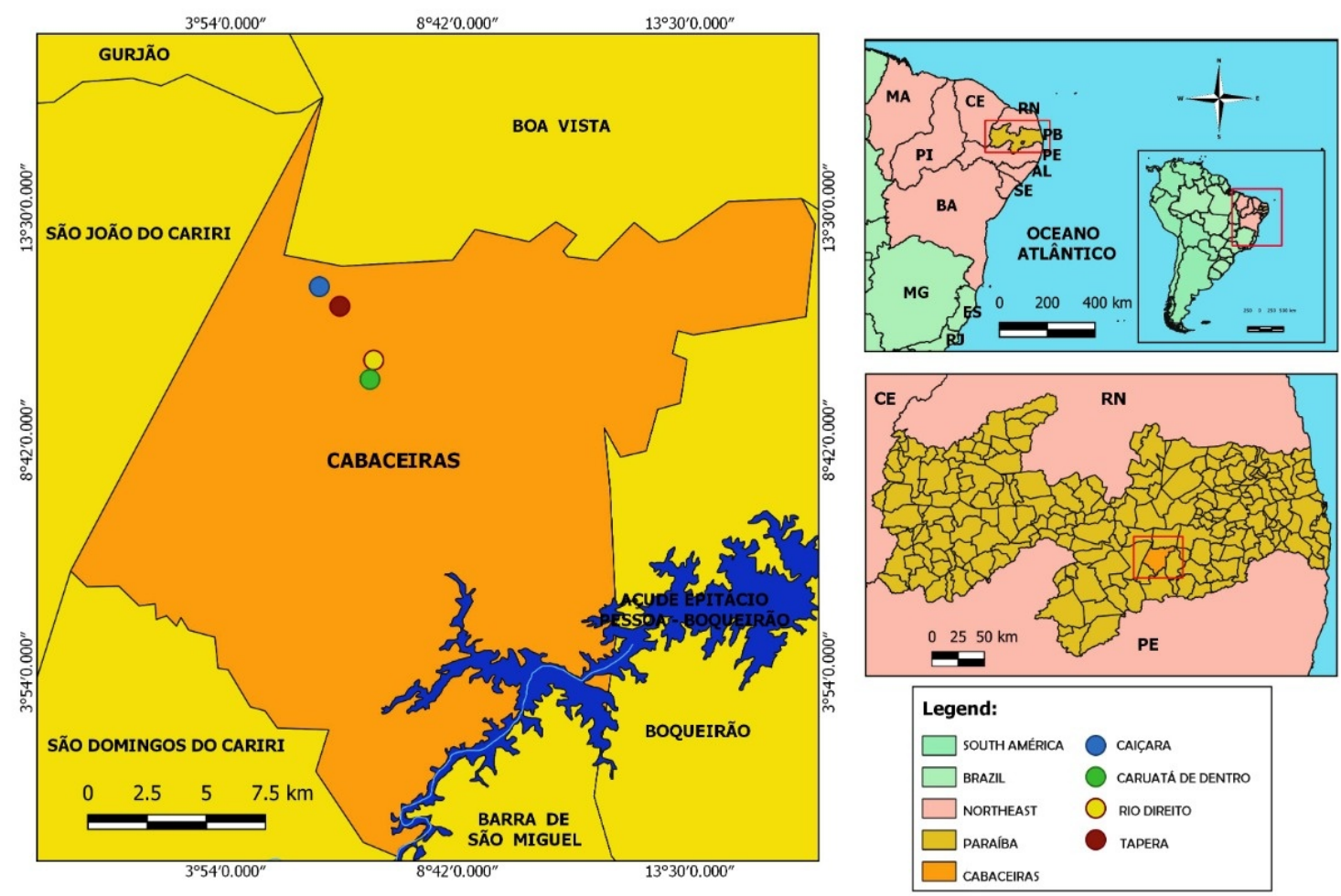

Datum: SIRGAS 2000 Projection: UTM: $24 S$

Figure 1. Location map of the municipality of Cabaceiras, Paraíba, northeastern Brazil. Photo: Diogo Fonseca (2020).

practices), and ex situ management through artificial propagation or planting (removal of vegetative parts of plants from their natural environment to anthropogenic areas) and transplantation (removal of the whole plant for planting in a controlled environment). Only residents who claimed to perform some type of cacti management participated in this study, totaling 17 informants (15 men and 2 women). All species cited by the informants were collected, herborized, identified, and deposited in the Herbarium "Jaime Coelho de Morais" of the Federal University of Paraíba, Campus II, Areia, Paraíba, Brazil.

Socio-economic description of rural communities

There are 14 residences in Tapera, 6 in Caiçara, 8 in Rio Direito, and 18 in Caruatá de Dentro. The residents of the communities of Tapera and Caiçara are farmers (men and women) who have performed economic activities focused on rural tourism and associated with the "Pai Matheus" Farm Hotel, which is included in the rural tourism cultural route in the region. Farmers are registered in the Rural Workers' Association of Tapera. They are visited monthly by a health agent and have access to medical care. There is no school in these communities and students are transported to attend classes in the urban center of Cabaceiras. In Tapera, there is a catholic chapel. The communities of Rio Direito and Caruatá de Dentro have family health care and are visited monthly by a health agent, who monitor the residents. The people in these communities use a room as a medical center with biweekly appointments. There is 
a public elementary school in these communities (Municipal School of Primary Education "Maria Neuly Dourado"). Primary and secondary students take a school bus to attend classes in Cabaceiras. These communities have two Rural Associations managed by different political representatives, in addition to a Catholic church.

\section{Data analysis}

The qualitative data obtained were analyzed through the interviewees' discourse interpretation (Mourão and Nordi 2003), based on the diverse individual competences union model (Hays 1976), which consists of considering all the information provided by the interviewees. Information was grouped by theme and used to interpret the results and to ground aspects of the discussion.

\section{RESULTS}

Forms of management were recorded for five species, which are prone to some kind of anthropogenic interference in natural (in situ) or domestic (ex situ) environments. Regarding the type of propagation, the informants explained they perform this practice by removing vegetative parts (cladodes) and/or individuals in the regeneration process (shoots) (Table 1). No collection, induction, promotion, and protection management were recorded in natural environments. Only Cereus jamacaru DC. subsp. jamacaru (mandacaru) has more than one form of management. Regarding the collection, there is a preference for some areas, such as yards, live fences, and areas for agropastoral activity.

All the informants reported planting Cereus jamacaru subsp. jamacaru. Pilosocereus pachycladus F. Ritter and
Pilosocereus gounellei (F.A.C. Weber) Byles \& Rowley subsp. gounellei are planted by eight and seven informants, respectively, and only two people reported planting Melocactus zehntneri (Britton \& Rose) Luetzelb. and Tacinga palmadora (Britton \& Rose) N.P. Taylor \& Stuppy (Table 1).

Cereus jamacaru subsp. jamacaru is the only species managed in wild environments through tolerance. This fact is confirmed mainly by the non-intentional removal of specimens, as the residents remove other plant species from agricultural environments but leave C. jamacaru subsp. jamacaru. Also, transplantation of propagules may occur in environments controlled or disturbed by anthropogenic activities. In both situations, C. jamacaru subsp. jamacaru specimens are maintained as a form of planning for future uses.

The specimens identified by the residents in ex situ environments are propagated by transplantation, using the vegetative part or the entire plant, which are subjected to special care for their development (Table 1).

Some species, such as M. zehntneri, were recorded as transplanted from young plants (shoots). P. pachycladus and $T$. palmadora are also removed from their natural habitat to be planted near the residences, in fences or edges of agricultural fields for ornamental purposes. P. gounellei subsp. gounellei specimens are planted by the propagation of vegetative parts (cladodes) in soil erosion areas for stabilization; thus, these plants are used in the recovery of degraded areas.

Some measures necessary for planting were mentioned as factors that favor plant growth. For C. jamacaru subsp. jamacaru, e.g., damaged cladodes and those with signs of diseases are removed to prevent contamination, and then the undamaged and healthy ones are planted. P. gounellei subsp. 
Table 1. Legend: Species and their respective management recorded in the rural communities of Caiçara, Tapera, Rio Direito, and Caruatá de Dentro in the municipality of Cabaceiras, Paraíba, Northeast Brazil. Use categories: $\mathrm{Ct}=$ construction; $\mathrm{Fo}=$ food; $\mathrm{Fu}=$ fuel; $\mathrm{Fd}=$ fodder; $\mathrm{Me}=$ medicinal; Ot = other uses; $\mathrm{Tc}=$ technology. Forms of management: ${ }^{*} \mathrm{TP}=$ Transplantation of Propagules; $\mathrm{T}=$ Tolerance. Types of propagation: VP = Vegetative Part; $\mathrm{S}=$ Shoots.

\begin{tabular}{|c|c|c|c|c|c|c|}
\hline Species & Voucher & Popular name & Uses & \multicolumn{2}{|c|}{$\begin{array}{c}\text { Forms of } \\
\text { management }\end{array}$} & $\begin{array}{c}\text { Types of } \\
\text { propagation }\end{array}$ \\
\hline $\begin{array}{l}\text { Melocactus zehntneri (Britton \& Rose) } \\
\text { Luetzelb. }\end{array}$ & 23.606 & Coroa de frade & Fo, Fd, Me, Ot & TP & & S \\
\hline Pilosocereus pachycladus F. Ritter & 23.421 & Facheiro & Fo, Fu, Ct, Fd, Me, Tc & TP & & S \\
\hline $\begin{array}{l}\text { Tacinga inamoena (K. Schum) N.P. Taylor } \\
\text { \& Stuppy }\end{array}$ & 23.419 & Cumbeba & Fo, Fd & & & \\
\hline $\begin{array}{l}\text { Tacinga palmadora (Britton \& Rose) N.P. } \\
\text { Taylor \& Stuppy }\end{array}$ & 23.420 & Palmatória & $\mathrm{Fd}, \mathrm{Ot}$ & TP & & S \\
\hline
\end{tabular}

gounellei and $M$. zehntneri have their vegetative parts removed for planting and $P$. pachycladus planting is performed using shoots. Another technique consists of letting the cacti vegetative part wither to be later planting in dry soil. The cacti cannot be planted in moist soil, because they do not withstand these conditions for its development.

After planting, some people perform ex situ management, a technique that helps in the development and protection of the species. The reports show that the residents have adopted practices that influence the number of specimens, subjecting them to conditions that contribute to their development after planting, such as the use of water for the growth of the planted ones. The use of a drip irrigation system was recorded in the communities, irrigating an area of Opuntia ficus-indica (L.) Mill., used as fodder, and also benefiting some $C$. jamacaru subsp. jamacaru specimens (Figure 2), which, according to the informants, would also be used for fodder purpose in the future.

In the dry season, the cacti near the residences are irrigated with water reused from household chores. Elimination of pests and domestic animals, which may impede the development of cacti, was another recorded form of ex situ management.

Moreover, the informants use rudimentary techniques such as the burning of cacti in natural areas to optimize the collection and facilitate fodder preparation for domestic animals. Thirteen people burn these plants and four do not burn them because they rear no domestic species or because they buy processed feed from industries. P. gounellei subsp. gounellei is one of the most used species (14 use citations), followed by $C$. jamacaru subsp. jamacaru (13 use citations), P. pachycladus (8 use citations), and $T$. palmadora (2 use citations) for fodder purposes.

With regards to preferences, farmers prefer to burn the cacti, partially cutting the branches, e.g., young branches, or burning all branches or even the entire plant. Young cacti are selected to be cut since they have non-lignified stems. C. jamacaru subsp. jamacaru specimens are not burnt, but their vegetative parts may be partially or fully cut.

Regarding cacti preparation for fodder purposes, some informants burn the cladodes of all the species collected. For this, they use "coivaras", which are fires 


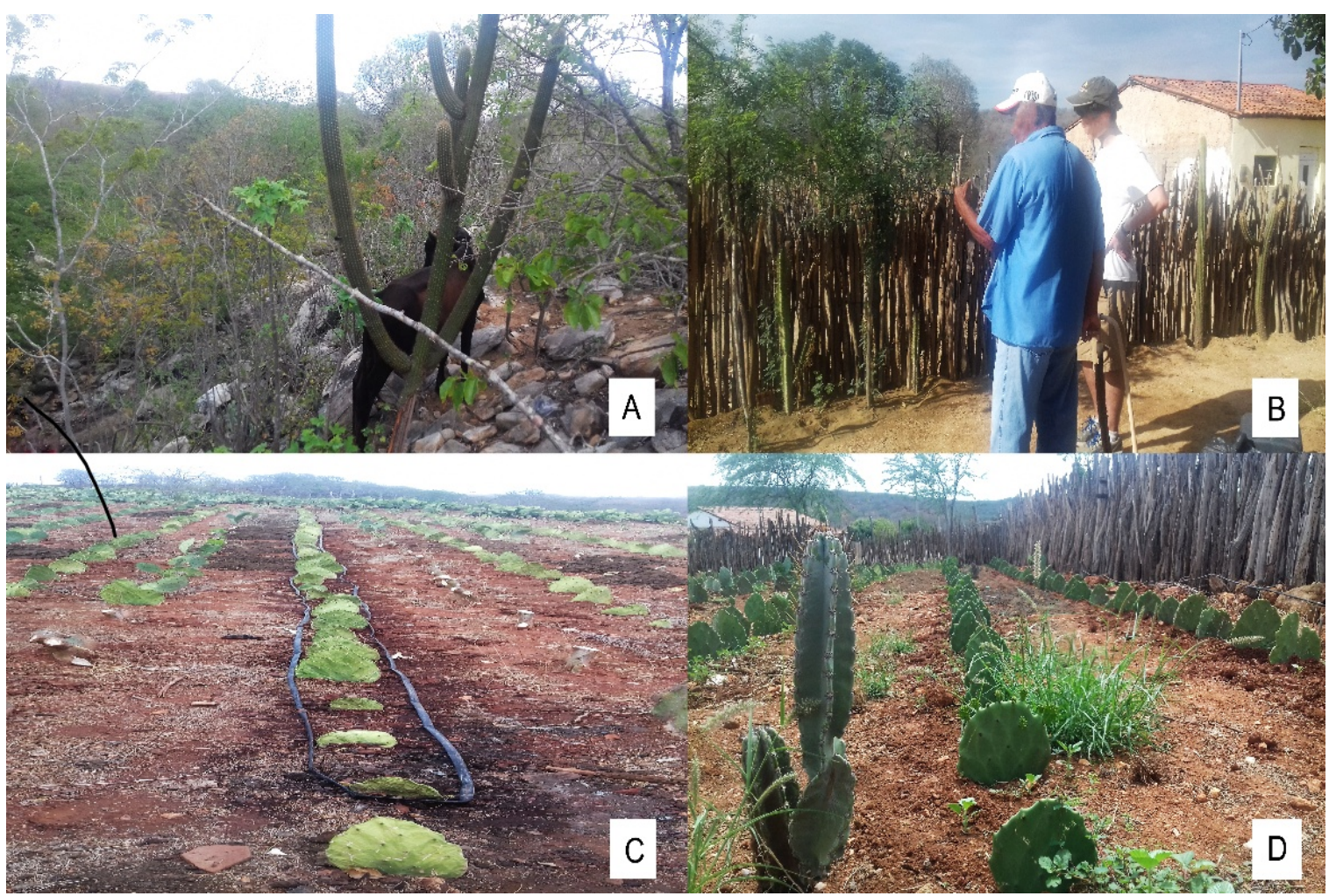

Figure 2. Vegetative propagation irrigated by dripping in the community of Tapera (Cabaceiras, Paraíba, northeastern Brazil). A: Pilosocereus pachycladus F. Ritter in natural areas for fodder purpose; B: Plantation of Cereus jamacaru DC. subsp. jamacaru and Pilosocereus pachycladus F. Ritter in live fences; C: Plantation of Opuntia ficus-indica (L.) Mill.; D: Associated cultivation of Opuntia ficus-indica (L.) Mill. and Cereus jamacaru DC. subsp. jamacaru Photo: Kamila Pedrosa, 2017.

made of species native to the Caatinga; then they take the animals to feed in the place where species were burnt or take the burnt species to feed the animals near the residences (Figure 3 ).

The species subjected to burning are collected in rangelands (near the residences), small mountains, close to rivers, small vegetable garden, and in areas of native vegetation, with different frequencies of collections according to the available time of each farmer; collections may be performed only on weekends or every day.

Depending on the abundance of species and their respective uses, some collection areas become the most preferred by the locals. P. gounellei subsp. gounellei and $C$. jamacaru subsp. jamacaru are often collected; due to more frequent use of these species, the residents collect them three times a day, on average, and/or every day.

\section{DISCUSSION}

The studied species are managed with a focus on the quality and maintenance of plants, as there is no evidence that people, in that region, perform traditional management in search of a specific objective. These nuances are investigated in different ways through the socio-ecological context of the populations (Casas et al. 2016b). In this way, local management characteristics indicate a continuous use of available species to meet current demands.

The informants have no interest in caring for the cacti in the wild area; however, they are careful not to cut the entire cactus so that 


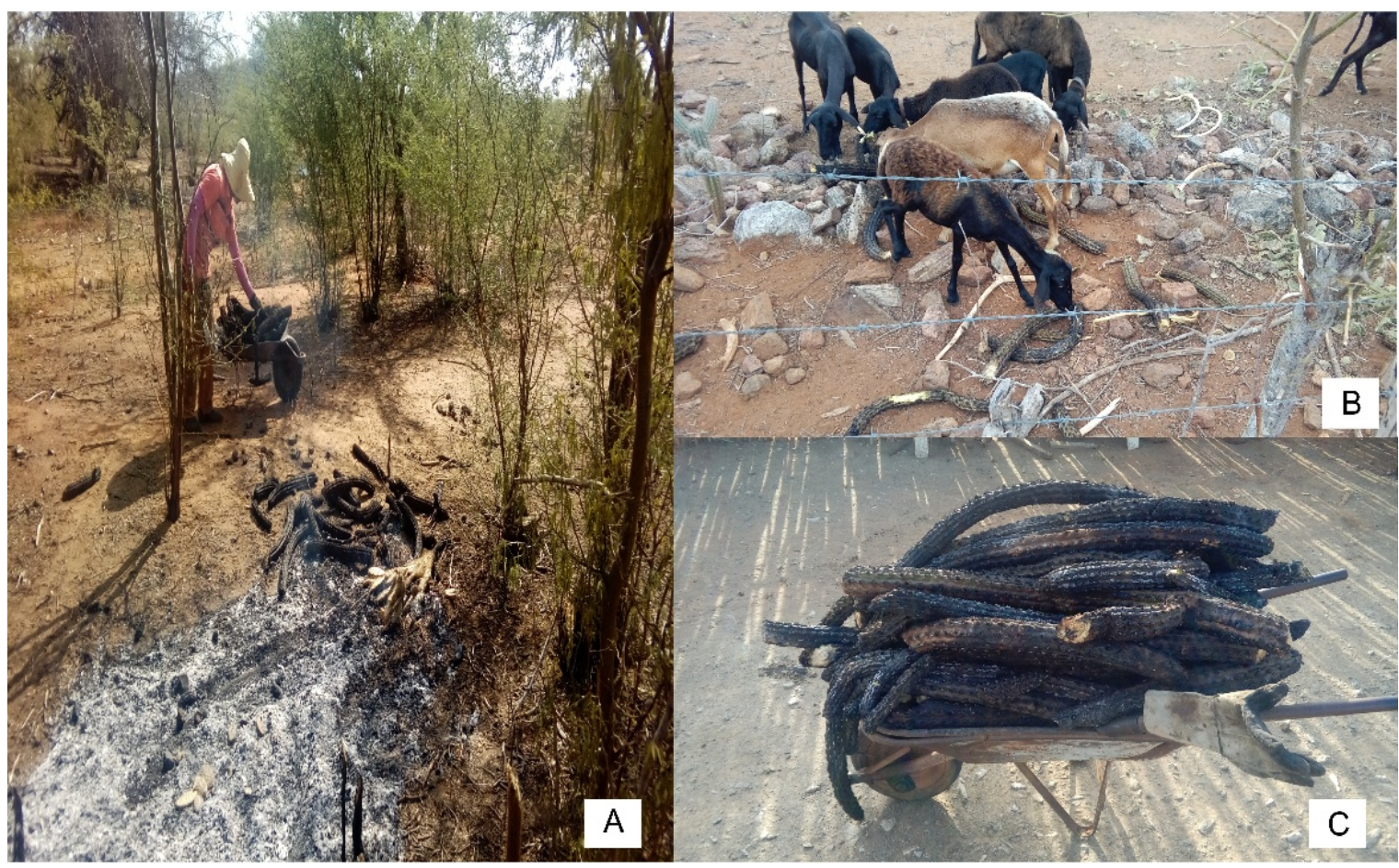

Figure 3. Pilosocereus pachycladus F. Ritter specimens subjected to burning for fodder purpose in the rural communities of Tapera, Caiçara, Caruatá de Dentro, and Rio Direito (Cabaceiras, Paraíba, northeastern Brazil). A: Burning performed by a resident; B: Animals feeding on burnt plants in loco; C: Use of a wheelbarrow to take the burnt vegetative parts to near the residence. Photo: Ribamar Lima and Thamires Carvalho, 2017.

it can regenerate. Nevertheless, cutting management of cladodes, recorded in our study, may be associated with some type of management for protection, as it was found in Mexico (Casas et al. 1997b, 2014, 2017). Concomitantly, informants' awareness of parsimoniously using the cacti in natural areas is considered in the literature as "tolerance management" (Casas et al. 2014). The tolerance management is typical of semi-arid regions, due to conservation activities and socio-cultural value of cacti for semi-arid populations, mainly for animal feed.

The techniques used for the management of these species are similar to those used for in situ management found in the literature (Casas et al. 1999, 2001, 2007). This fact leads us to reflect on the importance of cacti management to local populations since they prefer to plant these plants near their residences, rather than to manage them in natural areas of difficult access. The propagation of young plants is appreciated by people, as it is more likely to guarantee the development of specimens. However, the removal of young cacti for planting is motivated by their availability near the residents but it can be a limiting factor for the survival of these plants in natural environments (Godínez-Álvarez et al. 2005). Moreover, when people select vegetative parts for planting, non-relevant characteristics for plant development are excluded. This selective process, over time, may influence the frequency of specimens resistant to the attributes non-selected by people, as recorded for some columnar cacti native to Mexico (Casas et al. 2016b).

The management techniques performed near the residences optimize the use of the resource, causing the residents to spend 
less energy when collecting the species, and maximize cactus' utilitarian functions, both because of the number of specimens available next to the people and for ensuring forage production (Alves et al. 2017; Albuquerque et al. 2019).

Collection areas are associated with the abundance of species and their respective uses, becoming the areas most preferred by locals. In the study communities, cacti are collected for fodder purposes, in areas ranging from a more preserved vegetation to nearby residences.

On the other hand, there is evidence that collection areas may be related to the type of resource used and the social characteristics of rural communities, bearing in mind that food plants are usually consumed near areas where people develop agricultural activities (Cruz et al. 2013). Moreover, the frequency of use in collection areas is related to the practicality and the number of domestic animals to be fed, as reported by Lucena et al. (2015), Carvalho et al. (2019), and LimaNascimento et al. (2019), in studies conducted in the semi-arid region of Brazil.

The predominance of the use of these species is influenced by seasonality, which limits the productivity of animal feed (Santos et al. 2010). Thus, in semi-arid regions of Brazil, there is a fluctuation in the use and valorization of species during dry seasons. Under these conditions, local populations have used strategies such as burning cladodes of cacti where they are found, and this practice has reduced the time to transport animal feed by local populations; although, intense daily use causes stress and physiological limitation in cacti, especially in the Caatinga, as the species are sensitive to any anthropogenic changes (Cavalcante and Resende 2007).

Burning techniques may cause serious damage to the caatinga vegetation and, today, there is a concern regarding the synergism between the different chronic anthropogenic disorders in the face of climate changes (Rito et al. 2017). It is assumed that climate change can influence periods of intense drought in the semi-arid region, which therefore implies the distribution of these species (Bellard et al. 2012). Adverse environmental conditions may increase the recurrence of traditional management of cacti or affect their use by human populations (Lima-Nascimento et al. 2019).

Cereus jamacaru subsp. jamacaru is the farmers' favorite species of cacti, since it morphologically differs from other species of the Caatinga, presenting a larger size and fewer thorns, making its management easy, in addition to being palatable for cattle, goats, and sheep (Lucena et al. 2015; Lucena 2018). It is noteworthy that the techniques used in the management of $C$. jamacaru subsp. jamacaru, in other semi-arid regions, have led to incipient domestication processes of this species (Lucena 2018).

Reflecting on the importance of the residents for maintaining local populations of native species of Cactaceae in the study area, and on how these people influence cacti management and conservation, it can be stated that some species with characteristics that meet the demand of use are reproduced and consequently can contribute as an alternative for the local conservation of these species, corroborating the studies by Rangel-Landa et al. (2017) and Pedrosa et al. (2018). These authors recorded the importance of maintaining important useful species, which contribute to the maintenance of their future availability and therefore consisting of an alternative to conservation since it would no longer be necessary to remove the resource from its natural environment. 
The management practices recorded in this study show how much the efficacy of use and availability related to the forms of allocation, determined by residents, are important criteria for selecting strategies of use. However, it has been evidenced that practices that ensure the use of plant resources may be modulated by cognitive processes, as they vary in terms of use according to environmental or social factors (Santoro et al. 2018). Therefore, the ability of human beings to adapt to the environment is a relevant condition for developing strategies that make possible better use of plant resources in regions with marked climatic seasonality.

This scenario allows us to observe the extent to which management techniques optimize the use of species, in addition to providing strategies for restructuring management practices over time (Abbo et al. 2014; Casas et al. 2017). From this perspective, studies on the use and management of cacti species are increasingly necessary to verify the pattern of techniques used, in order to analyze how much the influence of people on the resources has changed plant structures over time. Therefore, studies on the conservation of species important to local populations, in dry forests, provide subsistence to socioecological systems, bearing in mind that the use of species will be increasingly motivated by local and global changes, leading people to resort to their traditional management.

\section{CONCLUSIONS}

Given the above, it is possible to elucidate the considerable cultural importance related to the uses of the study species by local populations. The species are managed in different ways but the ex situ propagation is the most prominent form of management.
Cereus jamacaru subsp. jamacaru has more information regarding care and uses. However, the management by burning techniques stands out as the main way of providing fodder throughout the year. This fact evidences the importance of developing projects for promoting the traditional management and conservation of these species.

\section{ACKNOWLEDGEMENTS}

The authors thank the informants of the study rural communities for their participation in the research, the professor Leonardo Pessoa Félix (CCA/UFPB) for the species identification, and the Coordenação de Aperfeiçoamento de Pessoal de Nível Superior (CAPES) for granting a master's scholarship to the first author.

\section{DATA AVAILABILITY}

\section{CONFLICTS OF INTEREST}

The authors declare no conflicts of interest.

\section{CONTRIBUTION STATEMENT}

KMP and TKNC collected and analyzed the data and wrote the manuscript; RFPL coordinated the field research and the writing of the manuscript. All authors read and approved the final version of the manuscript. 


\section{REFERENCES}

Abbo S, Lev-Yadun S, Gopher A (2014) The "Human Mind" as a common denominator in plant domestication. Journal of Experimental Botany 8:1917-1920.

Albuquerque UP, Lucena RFP, Lins-Neto EBF (2014) Selection of research participants. In: Albuquerque UP, Cunha IVFC, Lucena RFP, Alves RRN (eds) Methods and techniques in ethnobiology and ethnoecology. 2 ed. Springer: New York, pp. 300.

Albuquerque UP, Medeiros PM, Ferreira-Júnior WS, Silva TC, Silva RRV, Gonçalves-Souza, T (2019) Social-Ecological Theory of Maximization: Basic Concepts and Two Initial Models. Biological Theory doi 10.1007/s13752019-00316-8

Alves ASA, Nascimento ALB, Albuquerque UP (2017) Optimal Foraging Theory Perspectives on the Strategies of Itinerant Beekeepers in Semiarid Northeast Brazil. Human Ecology 45:345-355.

Alvares CA, Stape JL, Sentelhas PC, Gonçalves JL, Sparovek G (2013) Mapa de classificação climática de Köppen para o Brasil. Meteorologische Zeitschrift 6:711-728 doi: 10.1127 / 0941-2948 / 2013/0507

Apodaca P (2001) Cactus Stones: Symbolism and Representation In Southern California and Seri Indigenous Folk Art and Artifacts. Journal of California and Great Basin Anthropology 2:215-228.

Bellard C, Bertelsmeier C, Leadley P, Thuiller W, Courchamp $F$ (2012) Impacts of climate change on the future of biodiversity. Ecology Letters 15:365-377.

Blancas J, Casas A, Rangel-Landa S, MorenoCalles A, Torres I, Pérez-Negrón $E$, Solís L, Delgado-Lemus A, Parra F, Arellanes Y, Caballero J, Corts L, Lira R, Dávila P (2010) Plant anagement in the Tehuacán-Cuicatlán Valley, Mexico. Economic Botany 4:287-302.

Casas A, Caballero J, Mapes C, Zarates S (1997a) Manejo de la vegetacíon domesticacíon de plantas y origen de la agricultura em Mesoamerica. Boletín de la Sociedad Botánica 61:17-31.
Casas A, Pickersgill B, Caballero J, ValienteBanuet A (1997b) Ethnobotany and domestication in Xoconchtli, Stenocereus stellatus Cactaceae in the Tehuacán Valley and La Mixteca Baja, Mexico. Economic Botany 3:279-292.

Casas A, Caballero J, Vallente-Banuet, A (1999) Use, management and domestication of columnar cacti in South-Central Mexico: A historical perspective. Journal of Ethnobiology 1:71-95.

Casas A, Valiente-Banuet A, Viveros JL, Caballero J, Cortés I, Dávila P, Lira R, Rodríguez I (2001) Plant resources of the TehuacánCuicatlán Valley, Mexico. Economic Botany 55:129-166.

Casas A, Pérez-Negron E, Otero-Arnaiz A, Lucio JD, Ruíz-Duron ME, Parra F, Blancas JJ (2006) Manejo tradicional y conservacíon de la diversidade biológica de Cactáceas Columnares. In: Albuquerque UP, Almeida CFCBR (eds) Tópicos em conservação e etnobotânica de plantas alimentícias. NUPEEA, Recife, pp.75-92.

Casas A, Arnaiz-Otero A, Perrez-Negro E, Banuet-Valiente A (2007) Gestão in situ e domesticação de plantas na Mesoamérica. Annals of Botany 100:1101-1115.

Casas A, Camou A, Otero-Arnaiz A, RangelLanda S, Cruse-Sanders J, Solís L, Torres I, Delgado A, Moreno-Calles Al, Vallejo M, Guillén S, Blancas J, Parra F, Farfán-Heredia B, AguirreDugua X, Arellanes Y, Pérez-negrón E (2014) Manejo tradicional de biodiversidad $y$ ecossistemas em Mesoamérica: el Valle de Tehuacán. Investigación ambiental 2:23-44.

Casas A, Parra, F (2016a) El manejo de recursos naturales y ecossistemas: la sustentabilidade en el manejo de recursos genéticos. In: Casas A, Torres-Guevara J, Parra F (eds). Domesticación en el continente americano: Manejo de biodiversidade y evolución dirigida por las culturas del Nuevo Mundo. 1 ed. UNAM,UNALM, Morelia, México, pp. 25-50.

Casas A (2016b) Manejo y conservación in situ y ex situ de recursos genéticos. In: Casas $A$, Torres-Guevara J, Parra F (eds) Domesticación en el continente americano: Manejo de biodiversidad y evolución dirigida por las culturas del Nuevo Mundo. 1 ed. UNAM,UNALM, Morelia, México, pp. 346-359 
Casas A, Moreno-Calles Al, Vallejo M, Parra F (2017) Importancia actual y potencial de los recursos genéticos. In: Casas $A$, TorresGuevara J, Parra F (eds) Domesticación en el continente americano. 1 ed. UNAM,UNALM, México, pp. 51-73.

Cavalcanti NB, Resende GM (2007) Efeito de diferentes substratos no desenvolvimento de mandacaru (Cereus jamacaru P. DC.), facheiro (Pilosocereus pachycladus Ritter), xiquexique (Pilosocereus gounelli (A, Webwr EX K. Schum.) Bly. EX Rowl.) e coroa-de-frade (Melocactus bahiensis Britton \& Rose). Revista Caatinga 1: 28-35.

Carvalho TKN, Lucena CM, Lima JRF, Cruz DD, Lucena RFP (2019) Local botanical knowledge of cacti in the semi-arid region of Paraíba, northeastern Brazil. Ethnobotany Research and Applications 42:1-11.

Cruz MP, Peroni N, Albuquerque UP (2013) Knowledge, use and management of native wild edible plants from a seasonal dry forest (NE, Brazil). Journal of Ethnobiology and Ethnomedicine 9:79 doi:10.1186 / 1746-4269-979

Hays TE (1976) An empirical method for the identification of covert categories in ethnobiology. American Ethnologist 3:489-507.

Fernández-Alonso JL (2006) Nueva especie colombiana de Browningia (Cactaceae, Cactoideae, Browningieae) potencialmente promisoria para el país. Revista de la Academia Colombiana de Ciencias Exactas, Físicas y Naturales 114:19-30.

Fuentes VR (2005) Etnobotánica de Cactaceae em Cuba. In: González Torres LR, Palmadora A and Rodríguez A (Eds) Memorias del taller conservación de cactos Cubanos. La Habana: Jardín Botánico Nacional, Universidad de La Habana, Cuba, pp.15-24.

IBGE (Instituto Brasileiro de Geografia e Estatística) (2010) [http://censo2010.ibge.gov.br] Accessed 03 may 2018.

Gepts P (2004) Crop domestication as a longterm selection experiment Plant. Breeding Reviews 2:1-44.

Godínez-Alvarez H, Ríos-Casanova L, Pérez F (2005) Characteristics of seedling establishment of Stenocereus stellatus (Cactaceae) in the Tehuacán Valley, Mexico. The Southwestern Naturalist. 50:375-407.
González-Insuasti MS, Caballero J (2007) Managing plant resources: How intensive can it be? Humany Ecology 35:303-314.

Rangel-Landa S, Casas A, García-Frapolli E, Lira $R$ (2017) Sociocultural and ecological factors influencing management of edible and nonedible plants: The case of Ixcatlán, Mexico. Journal of Ethnobiology and Ethnomedicine 13:59.

Lima-Nascimento AM, Bento-Silva JS, Lucena CM, Lucena RFP (2019) Ethnobotany of native cacti in the northeast region of Brazil: can traditional use influence availability? Acta Botanica Brasilica 2:350-359 doi.org/ 10.1590/0102-33062019abb0166.

Lucena CM, Costa GM, Ferreira SR, Carvalho TKN, Marreiros NA, Alves CAB, Duarte DP, Lucena RFP (2012) Conhecimento local sobre cactáceas em comunidades rurais na mesorregião do sertão da Paraíba (Nordeste, Brasil). Biotemas (UFSC) 25:281-291.

Lucena CM, Lucena RFP, Costa GM, Carvalho TKN, Costa GGS, Alves RRN, Pereira DD, Ribeiro JES, ALVES CAB, Quirino ZGM, Nunes EM (2013) Use and knowledge of Cactaceae in Northeastern Brazil. Journal of Ethnobiology and Ethnomedicine 9:1-11.

Lucena CM, Carvalho TKN, Ribeiro JES, Quirino ZGM, Casas A, Lucena RFP (2015) Conhecimento botânico tradicional sobre cactáceas no semiárido do Brasil. Gaia Scientia 2:77-90.

Lucena CM (2018) Uso, Manejo e Processo de domesticação de Cereus jamacaru DC. subsp. jamacaru (Cactaceae) no Semiárido do Brasil. Tese de Doutorado, Universidade Federal da Paraíba, João Pessoa, Brasil

Lucena RFP, Lucena CM, Meiado MV, Cruz DD, Andrade MO, Casas A (2017) Uso, manejo y domesticación de cactáceas en Brasil. In: Casas A, Torres-Guevara J, Parra F (eds) Domesticación en el continente americano. Investigación para el manejo sustentable de recursos genéticos en el Nuevo Mundo. 1ed.México: Editorial Morevalladolid, pp. 311-325

Martorell C, Garcillán PP, Casillas F (2012) Ruderality in extreme-desert cacti? Population effects of chronic anthropogenic disturbance on Echinocereus lindsayi. Population Ecology 54:335-346. 
Nascimento SS, Alves JJA (2008) Ecoclimatologia do Cariri Paraibano. Revista Geográfica Acadêmica 3:28-41.

Moro MF, Silva IA, Araújo, FS, Nic-Lughadha E, Meagher TR, Martins FR (2015) The Role of Edaphic Environment and Climate in Structuring Phylogenetic Pattern in Seasonally Dry Tropical Plant Communities. Polos One 3:1-18.

Mourão JS, Nordi N (2003) Etnoecologia de pescadores artesanais do estuario do Rio Mamanguape, Paraiba, Brasil. Boletim Técnico do Instituto de Pesca 29:9-17.

Pedrosa KM, Lucena CM, Lucena RFP, Lopes SFL (2018) Traditional Techniques for the Management of Cactaceae in the Americas: The relationship between use and conservation. Ethnobiology Letters 2:276-282.

Queiroz LP, Cardoso D, Fernandes MF, Moro MF (2017) Diversity and Evolution of Flowering Plants of the Caatinga Domain. In: Silva JMC, Leal IR, Tabarelli M (eds). Caatinga: The Largest Tropical dry forest region in South America. Springer International Publishing (ebook), Cham, Switzerland, pp. 23-63.

Rangel-Landa S, Casas A, García-Frapolli E, Lira $R$ (2017) Sociocultural and ecological factors influencing management of edible and nonedible plants: the case of Ixcatlán, Mexico. Journal of Ethnobiology and Ethnomedicine 13:59.
Rito KF, Arroyo-Rodriguez V, Queiroz RT, Leal IR, Tabarelli M (2017) Precipitation mediates the effect of human disturbance on the Brazilian Caatinga vegetation. Journal of Ecology 3:828838.

Santoro FR, Nascimento ALB, Soldati GT, Ferreira-Junior WS, Albuquerque UP (2018) Evolutionary ethnobiology and cultural evolution: opportunities for research and dialog. Journal of Ethnobiology and Ethnomedicine 14:1-14.

Santos MVF, Lira AM, Dubeux-Júnior JCB, Guim A, Mello ACL, Cunha MV (2010) Potential of Caatinga forage plants in ruminant feeding. Revista Brasileira de Zootecnia 39:204-215.

Silva JGM, Silva DS, Ferreira MA, Lima GFCL, Melo AAS, Diniz MCNM (2005) Xiquexique (Pilosocereus gounellei (A. Weber ex K. Schum.) Bly. ex Rowl.) em substituição à silagem de sorgo (Sorghum bicolor L. Moench) na alimentação de vacas leiteiras. Revista Brasileira de Zootecnia 4:1408-1417.

Silva JMC, Barbosa LCF, Leal IR, Tabarelli M (2017) The Caatinga: Understanding the Challenges. In: Silva JMC, Leal IR, Tabarelli M (eds) Caatinga: The Largest Tropical dry forest region in South America. Springer International Publishing (ebook), Cham, Switzerland, pp.3-19.

Sbrissa FC, Melo AGC (2012) Caracterização morfológica e conservação de Arthrocereus odorus F. Ritter. Revista Científica Eletrônica de Engenharia Florestal 20:19-28.

Received: 22 April 2020

Accepted: 27 June 2020

Published: 01 July 2020 